\title{
Nitrogen Immobilization in Plant Growth Substrates: Clean Chip Residual, Pine Bark, and Peatmoss
}

\author{
Cheryl R. Boyer, ${ }^{1}$ H. Allen Torbert, ${ }^{2}$ Charles H. Gilliam, ${ }^{3}$ \\ Glenn B. Fain, ${ }^{3}$ Thomas V. Gallagher, ${ }^{4}$ and Jeff L. Sibley ${ }^{3}$ \\ ${ }^{1}$ Department of Horticulture, Forestry and Recreation Resources, Kansas State University, \\ 2021 Throckmorton Plant Sciences Center, Manhattan, KS 66506, USA \\ ${ }^{2}$ USDA-ARS National Soil Dynamics Laboratory, 411 South Donahue Drive, Auburn, AL 36832, USA \\ ${ }^{3}$ Department of Horticulture, Auburn University, 101 Funchess Hall, Auburn, AL 36849, USA \\ ${ }^{4}$ School of Forestry \& Wildlife Sciences, Auburn University, 602 Duncan Drive, Auburn, AL 36849, USA
}

Correspondence should be addressed to Cheryl R. Boyer, crboyer@k-state.edu

Received 6 January 2012; Accepted 5 March 2012

Academic Editor: Mark Reiter

Copyright ( $\odot 2012$ Cheryl R. Boyer et al. This is an open access article distributed under the Creative Commons Attribution License, which permits unrestricted use, distribution, and reproduction in any medium, provided the original work is properly cited.

\begin{abstract}
Rising costs of potting substrates have caused horticultural growers to search for alternative, lower-cost materials. Objectives of this study were to determine the extent of nitrogen immobilization and microbial respiration in a high wood-fiber content substrate, clean chip residual. Microbial activity and nitrogen availability of two screen sizes $(0.95 \mathrm{~cm}$ and $0.48 \mathrm{~cm})$ of clean chip residual were compared to control treatments of pine bark and peatmoss in a 60-day incubation experiment. Four rates $(0,1,2$, or $3 \mathrm{mg})$ of supplemental nitrogen were assessed. Peatmoss displayed little microbial respiration over the course of the study, regardless of nitrogen rate; followed by pine bark, $0.95 \mathrm{~cm}$ clean chip residual, and $0.48 \mathrm{~cm}$ clean chip residual. Respiration increased with increasing nitrogen. Total inorganic nitrogen (plant available nitrogen) was greatest with peatmoss; inorganic nitrogen in other treatments were similar at the 0,1 , and $2 \mathrm{mg}$ supplemental nitrogen rates, while an increase occurred with the highest rate (3 mg). Clean chip residual and pine bark were similar in available nitrogen compared to peatmoss. This study suggests that nitrogen immobilization in substrates composed of clean chip residual is similar to pine bark and can be treated with similar fertilizer amendments during nursery production.
\end{abstract}

\section{Introduction}

Pine bark $(\mathrm{PB})$ and peatmoss $(\mathrm{PM})$ have traditionally been used as nursery and greenhouse substrates in the US. These materials are becoming more costly to use in horticultural industries due to increasing fuel costs, reduced availability of $\mathrm{PB}$ [1], and environmental concerns over the use of PM for growing crops $[2,3]$. Finding alternative substrates as a way to reduce costs has become an important issue for growers.

One promising alternative substrate is CCR, a forest byproduct of the 'clean chip' industry. The 'clean chip' industry processes small caliper pine trees into uniform, bark-free material for making paper products. This procedure is conducted on site at pine plantations with in-field harvesting equipment. This equipment delimbs, debarks, and chips the material into the back of a chip van/truck for shipment to a pulp mill. The remaining material, composed of approximately $40 \%$ wood, $35 \%$ bark, $10 \%$ needles, and $15 \%$ indistinguishable fine material, is either spread back across the harvested area or processed once more through a grinder with 10.2 to $15.2 \mathrm{~cm}$ screens and sold to the pulp mills for boiler fuel. Currently, this leftover material composes around $25 \%$ of the site biomass and represents an income loss for forest landowners.

Clean chip residual has been evaluated (in a fresh state) for the production of several types of horticultural crops [4-7]. The residual material is obtained from loggers and further processed through a swinging hammer mill in order to produce material with reasonable particle size for horticultural use. Since this material is processed before use, 
it can be hammer milled to pass several different screen sizes, producing substrates that are suitable for a variety of crop types and container sizes. Boyer et al. [4] evaluated perennials, buddleia (Buddleja davidii 'Pink Delight'), and verbena (Verbena canadensis 'Homestead Purple') in CCR and reported similar results among all treatments. A further study indicated that the use of supplemental $\mathrm{N}$ (in addition to standard control release fertilizer) was not necessary for growth of buddleia as compared to PB [5]. Later, Boyer et al. [6] demonstrated that annual plants, ageratum (Ageratum houstonianum 'Blue Hawaii'), and salvia (Salvia superba 'Vista Purple') grown in CCR or in combinations of CCR and PM produced similarly sized plants when compared to a traditional PB substrate treated with the same fertilizer regime. Woody plants such as loropetalum (Loropetalum chinensis var. rubrum) were also shown to have adequate growth in several screen sizes of CCR (compared to PB) over the course of one year [7].

While crop growth in CCR has been equal to that displayed by plants grown in traditional substrates, questions remain regarding the high wood content of forest residuals (especially among growers). Since PB has a high lignin content, it is slow to decompose, and producing crops over a short-term growing season (and some long-term seasons) has not caused problems due to shrinkage of substrate during decomposition [8].

Gruda et al. [9] reported significant N-immobilization resulting in less tomato (Lycopersicon lycopersicum) plant growth in substrates composed of a $100 \%$ wood fiber product. $\mathrm{N}$-immobilization was calculated on the basis of $\mathrm{N}$ balance including $\mathrm{N}$-uptake by plants and residual mineral $\mathrm{N}$ in the substrates. Higher $\mathrm{N}$-immobilization was found by increasing $\mathrm{N}$-application rates. They determined that it is necessary to supply wood fiber substrates with nutrient solutions or fertilizer from the beginning of plant culture. Also, substrates without plants in this study (wood fiber and white $\mathrm{PM}$ ) exposed to the same environmental conditions showed the same tendencies in $\mathrm{N}$-immobilization as substrates with plants.

Concern has arisen over whether the high wood content of CCR will immobilize $\mathrm{N}$ to an extent that plants experience a reduction in growth early in the crop cycle. This is especially important in greenhouse crops where the first few days and weeks are critical to long-term crop growth. The objective of this study was to determine the extent of $\mathrm{N}$-immobilization in CCR, $\mathrm{PB}$, and PM in order to make recommendations regarding how to overcome such a production problem.

\section{Materials and Methods}

Clean chip residual used in this study was obtained from a 10- to 12-year-old loblolly pine (Pinus taeda) plantation near Atmore, AL, which was thinned and processed for clean chips using a total tree harvester (Peterson DDC-5000-G Portable Chip Plant, Peterson Pacific Corp., Eugene, OR) and a horizontal grinder with $10.2 \mathrm{~cm}$ screens (Peterson 4700B Heavy Duty Horizontal Grinder, Peterson Pacific Corp., Eugene, OR). The material was further processed through a swinging
TABLe 1: Physical properties of clean chip residual, pine bark, and peatmoss substrates. ${ }^{\mathrm{Z}}$

\begin{tabular}{lcccc}
\hline Substrates $^{\mathrm{y}}$ & $\begin{array}{c}\text { Air } \\
\text { space }^{\mathrm{x}}\end{array}$ & $\begin{array}{c}\text { Container } \\
\text { capacity } \\
(\% \mathrm{Vol})\end{array}$ & $\begin{array}{c}\text { Total } \\
\text { porosity }\end{array}$ & $\begin{array}{c}\text { Bulk density } \\
\left(\mathrm{g} \cdot \mathrm{cm}^{-3}\right)^{\mathrm{u}}\end{array}$ \\
\hline $0.48 \mathrm{~cm} \mathrm{CCR}$ & $28 \mathrm{~b}^{\mathrm{t}}$ & $57 \mathrm{~b}$ & $85 \mathrm{~b}$ & $0.22 \mathrm{a}$ \\
$0.95 \mathrm{~cm} \mathrm{CCR}$ & $48 \mathrm{a}$ & $42 \mathrm{~d}$ & $90 \mathrm{~b}$ & $0.19 \mathrm{~b}$ \\
PB & $31 \mathrm{~b}$ & $48 \mathrm{c}$ & $79 \mathrm{c}$ & $0.18 \mathrm{~b}$ \\
PM & $11 \mathrm{c}$ & $87 \mathrm{a}$ & $98 \mathrm{a}$ & $0.11 \mathrm{c}$ \\
\hline
\end{tabular}

${ }^{2}$ Analysis performed using the North Carolina State University porometer.

${ }^{y}$ CCR: clean chip residual, PB: pine bark, and PM: sphagnum peatmoss.

${ }^{\mathrm{x}}$ Air space is the volume of water drained from the sample/volume of the sample.

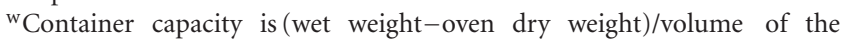
sample.

${ }^{v}$ Total porosity is container capacity + air space.

ubulk density after forced-air drying at $105^{\circ} \mathrm{C}\left(221.0^{\circ} \mathrm{F}\right)$ for $48 \mathrm{~h}$.

${ }^{t}$ Means within column followed by the same letter are not significantly different based on Waller-Duncan $k$ ratio $t$-tests at $\alpha=0.05(n=3)$.

hammer mill (no. 30; C.S. Bell, Tifton, $\mathrm{OH}$ ) with either a $0.95 \mathrm{~cm}$ or $0.48 \mathrm{~cm}$ screen to produce two CCR products for testing. These two CCR particle sizes were compared with $\mathrm{PB}$ and $\mathrm{PM}$ (Table 1). Pine bark used in this study was obtained from Pineywoods Mulch Company (Alexander City, AL). Peatmoss was obtained from Premier Horticulture, Inc. (Quakertown, PA) and was tested to confirm that no supplemental $\mathrm{N}$ had been added prior to use in this study.

Substrate air space (AS), container capacity (CC), and total porosity (TP) were determined following procedures described by Bilderback et al. [10]. Substrate bulk density (BD) $\left(\mathrm{g} \cdot \mathrm{cm}^{-3}\right)$ was determined from $347.5 \mathrm{~g} \cdot \mathrm{cm}^{-3}$ samples dried in a $105^{\circ} \mathrm{C}$ forced-air oven for $48 \mathrm{~h}$. Substrates were analyzed for particle size distribution (PSD) by passing a $100 \mathrm{~g}$ air dried sample through $12.5,9.5,6.35,3.35,2.36,2.0$, $1.4,1.0,0.5,0.25$, and $0.11 \mathrm{~mm}$ sieves with particles passing the $0.11 \mathrm{~mm}$ sieve collected in a pan. Sieves were shaken for 3 min with a Ro-Tap (Ro-Tap RX-29, W.S. Tyler, Mentor, $\mathrm{OH}$ ) sieve shaker (278 oscillations/min, $159 \mathrm{taps} / \mathrm{min}$ ). Substrate samples (four reps per treatment) were further evaluated for soilless media nutrient analysis (Brookside Laboratories, Inc., New Knoxville, OH). The material was ground and screened before saturated media extracts (water based) were prepared from the samples. Substrate $\mathrm{pH}, \mathrm{EC}, \mathrm{NO}_{3}$, $\mathrm{NH}_{4}$, and all other nutrients were measured using this water extract. Plant available $\mathrm{NO}_{3}$ and $\mathrm{NH}_{4}$ were determined using flow injection analysis (FIAlab-2500, FIAlab Instruments, Bellevue, WA), and $\mathrm{Ca}, \mathrm{Mg}, \mathrm{P}, \mathrm{K}, \mathrm{Na}, \mathrm{SO}_{4}, \mathrm{~B}, \mathrm{Mn}, \mathrm{Zn}, \mathrm{Fe}$, and $\mathrm{Cu}$ were determined by microwave digestion with inductively coupled plasma-emission spectrometry (ICP) (Thermo Jarrell Ash 6500 ICAP series, Offenbach, Germany).

An incubation study was conducted at the USDAARS National Soil Dynamics Laboratory in Auburn, AL to determine $\mathrm{N}$ mineralization/immobilization and microbial activity of each of the four substrate materials. A completely randomized design (CRD) with 272 experimental units was conducted. Treatment structure was factorial with four substrates by four $\mathrm{N}$ rates by four sample dates, each with four 
replications. There were also 16 units (four for each collection date) without substrate, serving as ambient $\mathrm{CO}_{2}$ traps. The incubation procedure consisted of weighing $20 \mathrm{~g}$ (dry weight basis) of substrate into plastic containers. Deionized water was added to adjust samples to consistent moisture content. Moisture content was determined by saturating $20 \mathrm{~g}$ of each substrate with deionized water and recording wet weight (after draining to simulate CC) and dry weight (after drying in an oven at $105^{\circ} \mathrm{C}$ for $48 \mathrm{~h}$ ). The change in weight (wet minus dry) divided by the wet weight multiplied by 100 equals the percent (\%) of moisture content (average of three subsamples). Each substrate had different percent of moisture contents, and subsequently an appropriate amount of deionized water was added to each sample in order to bring the moisture of the substrate up to CC. Container capacity is the amount of water in a just-drained container substrate. Four rates of supplemental $\mathrm{N}(0,1,2$, and $3 \mathrm{mg}$ of $\mathrm{N}$ added by the addition of $0,0.5,1.0$, or $1.5 \mathrm{~mL}$ of $2000 \mathrm{ppm}$ stock solution of $\mathrm{NH}_{4} \mathrm{NO}_{3}$ ) were added to each of the four substrates in the study. The containers were placed in sealed glass jars with $10 \mathrm{~mL}$ of water for humidity control and a vial containing $10 \mathrm{~mL}$ of $1 \mathrm{M} \mathrm{NaOH}$ as a $\mathrm{CO}_{2}$ trap. The jars were incubated in the dark at $25^{\circ} \mathrm{C}$ and removed after $7,15,30$, and 60 days. Carbon mineralization, which is a direct measurement of total microbial respiration, was measured in this study. Carbon dioxide in the $\mathrm{NaOH}$ traps was determined by titrating the excess base with $1 \mathrm{M} \mathrm{HCl}$ in the presence of $\mathrm{BaCl}_{2}$. All traps were measured at each sampling date, and fresh $\mathrm{NaOH}$ traps were placed in the jars remaining to be sampled at later dates. At each sampling date, a set of samples were measured for inorganic $\mathrm{N}$ concentration. Samples were extracted with a $2 \mathrm{~N} \mathrm{KCl}$ solution and measured for $\mathrm{NH}_{4}-\mathrm{N}$ and $\mathrm{NO}_{3}-\mathrm{N}$ using a Model 680 Microplate Reader (Bio-Rad Laboratories Inc., Hercules, CA). Inorganic $\mathrm{N}$ was calculated as the sum of $\mathrm{NH}_{4}$ and $\mathrm{NO}_{3}$. Potential $\mathrm{N}$ mineralization was the difference between final and initial inorganic $\mathrm{N}$ contents.

Data were analyzed using Waller-Duncan $k$ ratio $t$-tests $(P \leq 0.05)$ and a statistical software package (SAS Institute, Cary, NC). Data were analyzed separately for each sampling date.

\section{Results and Discussion}

3.1. Substrate Physical and Chemical Properties. Physical properties of the four substrates tested varied (Table 1). Each substrate had significantly different AS with $0.95 \mathrm{~cm}$ CCR having the greatest (48\%) and PM having the least (11\%). Container capacity was also different for each substrate; however, PM had the greatest CC (87\%), as expected, and PB had the least CC (48\%). Both CCR treatments were similar in TP but were between of $98 \%$ for PM and 79\% for PB. Bulk density was greatest for $0.48 \mathrm{~cm} \mathrm{CCR}\left(0.22 \mathrm{~g} \cdot \mathrm{cm}^{-3}\right)$ and least for PM $\left(0.11 \mathrm{~g} \cdot \mathrm{cm}^{-3}\right)$.

Particle size analysis revealed that $0.48 \mathrm{~cm}$ CCR had the least amount of coarse particles $(0.8 \%)$, while PM had the greatest amount of coarse particles (38\%) (Table 2). Pine bark and $0.95 \mathrm{~cm}$ CCR were similar $(30 \%$ and $27 \%)$ for coarse particles. Both CCR substrates had the highest amount of medium-sized particles $(48 \%$ for $0.48 \mathrm{~cm}$ and $50 \%$ for $0.95 \mathrm{~cm}$ ). Pine bark had $38 \%$ medium-sized particles and PM had $31 \%$. The greatest percentage of fine particles was measured in $0.48 \mathrm{~cm}$ CCR (51\%) followed by PM (31\%), PB (32\%), and $0.95 \mathrm{~cm} \mathrm{CCR} \mathrm{(24 \% ).}$

Substrate $\mathrm{pH}$ was significantly different for each substrate (Table 3). Clean chip residual screened at $0.95 \mathrm{~cm}$ had the highest $\mathrm{pH}$ (5.5) while $0.48 \mathrm{~cm}$ had a pH of 5.0. Peatmoss had the next highest $\mathrm{pH}$ (4.8) while $\mathrm{PB}$ had the lowest $\mathrm{pH}$ (4.1). Peatmoss and $\mathrm{PB}$ generally require lime addition to raise the $\mathrm{pH}$ for adequate plant culture. This may not be needed for substrates composed of CCR as its $\mathrm{pH}$ is already in an acceptable range for plant growth. Electrical conductivity was in the typical range for plant production, though each substrate was different (from 0.15 to $0.29 \mathrm{mS} \cdot \mathrm{cm}^{-1}$ ).

Substrate chemical analysis revealed that PM had a significantly higher amount of $\mathrm{NO}_{3}-\mathrm{N}(39.0 \mathrm{ppm})$ than all other treatments (0.1-0.2 ppm) (Table 3). Values for $\mathrm{NH}_{4}-\mathrm{N}$ were all low (from 0.1 to $0.4 \mathrm{ppm}$ ). Potassium was high in all substrates except PM (48.2-84.6 ppm versus $6.9 \mathrm{ppm})$. Calcium was greatest in PM (27.7 ppm) and least in the CCR treatments (from 5.3 to $9.1 \mathrm{ppm}$ ). Magnesium was also greatest in PM (28.3 ppm) and least in CCR (2.6 to $7.0 \mathrm{ppm})$. Sulfur was high in PB (50.9 ppm) and low in $0.95 \mathrm{~cm}$ CCR (7.7\%). Iron, $\mathrm{Mn}$, and $\mathrm{Zn}$ were higher in $0.48 \mathrm{~cm}$ CCR than all other treatments; however, these differences are not meaningful in a production context.

3.2. Microbial Respiration. Microbial respiration (MR) was evaluated at each sampling date (Table 4). Peatmoss consistently had the least microbial respiration regardless of date or supplemental $\mathrm{N}$ rate. The greatest microbial respiration occurred with the CCR treatments. As particle size decreased $(0.48 \mathrm{~cm})$, microbial respiration increased. Also, as $\mathrm{N}$ rate increased, microbial respiration increased in CCR and PB.

Microbial respiration at 7 days after treatment (DAT) showed that at each $\mathrm{N}$ rate, $0.48 \mathrm{~cm}$ CCR had the greatest microbial respiration followed by $0.95 \mathrm{~cm}$ CCR, PB, and PM (Table 4). For $0.48 \mathrm{~cm}$ and $0.95 \mathrm{~cm} \mathrm{CCR,} \mathrm{microbial} \mathrm{respira-}$ tion was highest with $2 \mathrm{mg} \mathrm{N}$ and decreased significantly as $\mathrm{N}$ rate decreased. Pine bark had significantly higher microbial respiration at $2 \mathrm{mg} \mathrm{N}$ than at 0 and $1 \mathrm{mg} \mathrm{N}$ (each was different from each other).

At 15 DAT, $0.48 \mathrm{~cm}$ CCR ( 0 and $1 \mathrm{mg} \mathrm{N}$ rates) had the greatest microbial respiration followed by $0.95 \mathrm{~cm}$ CCR, PB, and PM (Table 4). At 2 and $3 \mathrm{mg} \mathrm{N}$, the CCR treatments switched with $0.95 \mathrm{~cm}$ CCR having more microbial respiration than $0.48 \mathrm{~cm}$. For $0.48 \mathrm{~cm}$ and $0.95 \mathrm{~cm}$ CCR, MR was highest with $2 \mathrm{mg} \mathrm{N}$ and decreased significantly as $\mathrm{N}$ rate decreased. Pine bark microbial respiration was similar at the three highest $\mathrm{N}$ rates, and although 0 and $1 \mathrm{mg} \mathrm{N}$ had less microbial respiration they were similar to each other. There were no differences in microbial respiration for PM at any $\mathrm{N}$ rate.

The greatest microbial respiration at $30 \mathrm{DAT}$ for $0 \mathrm{mg}$ $\mathrm{N}$ was with $0.48 \mathrm{~cm}$ CCR followed by $0.95 \mathrm{~cm}$ CCR, PB, and PM (Table 4). At 1 and $2 \mathrm{mg} \mathrm{N}$ both CCR treatments were similar, but $\mathrm{PB}$ followed by $\mathrm{PM}$ had less microbial 
TABLE 2: Particle size analysis of clean chip residual, pine bark, and peatmoss substrates.

\begin{tabular}{|c|c|c|c|c|c|}
\hline \multirow{2}{*}{ U.S. standard sieve no. } & \multirow{2}{*}{ Sieve opening $(\mathrm{mm})$} & \multicolumn{4}{|c|}{ Substrate $^{z}$} \\
\hline & & $0.48 \mathrm{~cm} \mathrm{CCR}$ & $0.95 \mathrm{~cm} \mathrm{CCR}$ & $\mathrm{PB}$ & PM \\
\hline $1 / 2$ & 12.50 & $0.0 \mathrm{a}^{\mathrm{y}}$ & $0.0 \mathrm{a}$ & $0.0 \mathrm{a}$ & $2.2 \mathrm{a}$ \\
\hline $3 / 8$ & 9.50 & $0.0 \mathrm{~b}$ & $0.0 \mathrm{~b}$ & $0.1 \mathrm{~b}$ & $8.2 \mathrm{a}$ \\
\hline $1 / 4$ & 6.35 & $0.0 \mathrm{~d}$ & $2.7 \mathrm{c}$ & $6.0 \mathrm{~b}$ & $11.0 \mathrm{a}$ \\
\hline 6 & 3.35 & $0.8 \mathrm{c}$ & $23.9 \mathrm{a}$ & $24.0 \mathrm{a}$ & $17.0 \mathrm{~b}$ \\
\hline 8 & 2.36 & $8.8 \mathrm{c}$ & $20.0 \mathrm{a}$ & $12.6 \mathrm{~b}$ & $9.1 \mathrm{c}$ \\
\hline 10 & 2.00 & $7.9 \mathrm{a}$ & $8.1 \mathrm{a}$ & $5.0 \mathrm{~b}$ & $3.5 \mathrm{c}$ \\
\hline 14 & 1.40 & $19.0 \mathrm{a}$ & $13.2 \mathrm{~b}$ & $11.3 \mathrm{c}$ & $9.0 \mathrm{~d}$ \\
\hline 18 & 1.00 & $12.4 \mathrm{a}$ & $8.2 \mathrm{~b}$ & $9.1 \mathrm{~b}$ & $9.0 \mathrm{~b}$ \\
\hline 35 & 0.50 & $13.0 \mathrm{~b}$ & $7.7 \mathrm{c}$ & $13.8 \mathrm{ab}$ & $15.1 \mathrm{a}$ \\
\hline 60 & 0.25 & $12.1 \mathrm{a}$ & $7.8 \mathrm{~b}$ & 8.4 b & $9.4 \mathrm{~b}$ \\
\hline 140 & 0.11 & $15.1 \mathrm{a}$ & $7.0 \mathrm{~b}$ & $5.1 \mathrm{~b}$ & $5.0 \mathrm{~b}$ \\
\hline 270 & 0.05 & $5.8 \mathrm{a}$ & $0.9 \mathrm{c}$ & $2.5 \mathrm{~b}$ & $1.1 \mathrm{c}$ \\
\hline pan & 0.00 & $5.1 \mathrm{a}$ & $0.5 \mathrm{c}$ & $2.1 \mathrm{~b}$ & $0.4 \mathrm{c}$ \\
\hline \multicolumn{6}{|c|}{ Texture $^{\mathrm{x}}$} \\
\hline Coarse & & $0.8 \mathrm{c}$ & $26.6 \mathrm{~b}$ & $30.0 \mathrm{~b}$ & $38.3 \mathrm{a}$ \\
\hline Medium & & $48.0 \mathrm{a}$ & $49.5 \mathrm{a}$ & $38.0 \mathrm{~b}$ & $31.0 \mathrm{c}$ \\
\hline Fine & & $51.2 \mathrm{a}$ & $23.9 c$ & $32.0 \mathrm{~b}$ & $30.7 \mathrm{~b}$ \\
\hline
\end{tabular}

${ }^{2}$ CCR: clean chip residual, PB: pine bark, and PM: sphagnum peatmoss.

y Percent weight of sample collected on each screen, means within row followed by the same letter are not significantly different based on Waller-Duncan $k$ ratio $t$-tests at $\alpha=0.05(n=3)$.

${ }^{\mathrm{x}}$ Coarse: $>3.35 \mathrm{~mm}$, Medium: $>1.00-<3.35 \mathrm{~mm}$ and Fine: $<1.0 \mathrm{~mm}$.

TABLE 3: Chemical properties of clean chip residual, pine bark, and peatmoss substrates.

\begin{tabular}{|c|c|c|c|c|c|c|c|}
\hline \multirow{2}{*}{ Substrate ${ }^{z}$} & \multirow{2}{*}{$\mathrm{pH}$} & \multirow{2}{*}{$\mathrm{EC}\left(\mathrm{mS} \cdot \mathrm{cm}^{-1}\right)^{\mathrm{y}}$} & \multicolumn{5}{|c|}{ Substrate micronutrient content $\mathrm{t}^{\mathrm{x}}$} \\
\hline & & & $\mathrm{B}(\mathrm{ppm})$ & $\mathrm{Fe}(\mathrm{ppm})$ & $\mathrm{Mn}(\mathrm{ppm})$ & $\mathrm{Cu}(\mathrm{ppm})$ & $\mathrm{Zn}(\mathrm{ppm})$ \\
\hline $0.48 \mathrm{~cm} \mathrm{CCR}$ & $5.0 \mathrm{~b}^{\mathrm{w}}$ & $0.21 \mathrm{~b}$ & $0.23 \mathrm{a}$ & $3.7 \mathrm{a}$ & $2.3 \mathrm{a}$ & $0.01 \mathrm{~b}$ & $0.28 \mathrm{a}$ \\
\hline $0.95 \mathrm{~cm} \mathrm{CCR}$ & $5.5 \mathrm{a}$ & $0.15 \mathrm{c}$ & $0.17 \mathrm{~b}$ & $2.1 \mathrm{~b}$ & $0.6 \mathrm{~b}$ & $0.02 \mathrm{ab}$ & $0.06 \mathrm{c}$ \\
\hline $\mathrm{PB}$ & $4.1 \mathrm{~d}$ & $0.23 \mathrm{~b}$ & $0.16 \mathrm{~b}$ & $1.3 \mathrm{c}$ & $1.0 \mathrm{~b}$ & $0.03 \mathrm{a}$ & $0.16 \mathrm{~b}$ \\
\hline \multirow[t]{3}{*}{ PM } & $4.8 \mathrm{c}$ & $0.29 \mathrm{a}$ & $0.13 c$ & $0.2 \mathrm{~d}$ & $0.2 \mathrm{c}$ & $0.01 \mathrm{~b}$ & $0.05 \mathrm{c}$ \\
\hline & \multicolumn{7}{|c|}{ Substrate macronutrient content } \\
\hline & $\mathrm{NO}_{3}-\mathrm{N}(\mathrm{ppm})$ & $\mathrm{NH}_{4}-\mathrm{N}(\mathrm{ppm})$ & $\mathrm{P}(\mathrm{ppm})$ & $\mathrm{K}(\mathrm{ppm})$ & $\mathrm{Ca}(\mathrm{ppm})$ & $\mathrm{Mg}(\mathrm{ppm})$ & $\mathrm{SO}_{4}(\mathrm{ppm})$ \\
\hline $0.48 \mathrm{~cm} \mathrm{CCR}$ & $0.1 \mathrm{~b}$ & $0.2 \mathrm{~b}$ & $4.1 \mathrm{a}$ & $84.6 \mathrm{a}$ & $9.1 \mathrm{c}$ & $7.0 \mathrm{c}$ & $15.8 \mathrm{c}$ \\
\hline $0.95 \mathrm{~cm} \mathrm{CCR}$ & $0.2 \mathrm{~b}$ & $0.4 \mathrm{a}$ & $1.4 \mathrm{~b}$ & $48.2 \mathrm{~b}$ & $5.3 \mathrm{~d}$ & $2.6 \mathrm{~d}$ & $7.7 \mathrm{~d}$ \\
\hline PB & $0.1 \mathrm{~b}$ & $0.1 \mathrm{~b}$ & $4.0 \mathrm{a}$ & $52.5 \mathrm{~b}$ & $16.2 \mathrm{~b}$ & $11.5 \mathrm{~b}$ & $50.9 \mathrm{a}$ \\
\hline PM & $39.0 \mathrm{a}$ & $0.1 \mathrm{a}$ & $1.6 \mathrm{~b}$ & $6.9 c$ & $27.7 \mathrm{a}$ & $28.3 \mathrm{a}$ & $29.5 \mathrm{~b}$ \\
\hline
\end{tabular}

${ }^{z}$ CCR: clean chip residual, PB: pine bark, PM: sphagnum peatmoss.

${ }^{\mathrm{y}} 1 \mathrm{mS} \cdot \mathrm{cm}^{-1}=1 \mathrm{mmho} / \mathrm{cm}$.

${ }^{x}$ Substrate analysis performed on nonamended samples; N: nitrogen, P: phosphorous, K: potassium, Ca: calcium, Mg: magnesium, S: sulfur, B: boron, Fe: iron, Mn: manganese, Cu: copper, $\mathrm{Zn}$ : zinc, and $1 \mathrm{ppm}=1 \mathrm{mg} \cdot \mathrm{kg}^{-1}$.

${ }^{\mathrm{w}}$ Means within column followed by the same letter are not significantly different based on Waller-Duncan $k$ ratio $t$-tests $(\alpha=0.05, n=3)$.

respiration. At the highest $\mathrm{N}$ rate, $0.95 \mathrm{~cm} \mathrm{CCR}$ had the greatest microbial respiration followed by $0.48 \mathrm{~cm}$ CCR, PB, and PM. For $0.48 \mathrm{~cm}$ CCR the greatest microbial respiration was with 1 and $2 \mathrm{mg} \mathrm{N}$, while 0 and $3 \mathrm{mg} \mathrm{N}$ had less microbial respiration. For $0.95 \mathrm{~cm}$ CCR and $\mathrm{PB}$ only $0 \mathrm{mg}$ $\mathrm{N}$ was significantly less than other $\mathrm{N}$ rates. There were no differences in microbial respiration for $\mathrm{PM}$ at any $\mathrm{N}$ rate.
Microbial respiration at 60 DAT showed that at 0 and $3 \mathrm{mg} \mathrm{N}$ rate, both CCR treatments had the highest microbial respiration, followed by $\mathrm{PB}$ and $\mathrm{PM}$ (Table 4). At 1 and $2 \mathrm{mg}$ $\mathrm{N}$ rates, $0.95 \mathrm{~cm}$ CCR had the greatest microbial respiration followed by $0.48 \mathrm{~cm}$ CCR, PB, and PM. For $0.48 \mathrm{~cm} \mathrm{CCR}$ and PM there were no differences across $\mathrm{N}$ rates. For $0.95 \mathrm{~cm}$ $\mathrm{CCR}$, only the highest rate of $\mathrm{N}$ had less microbial respiration 
TABLE 4: Microbial respiration in clean chip residual, pine bark and peatmoss substrates.

\begin{tabular}{|c|c|c|c|c|c|}
\hline \multirow{2}{*}{ Substrate $^{z}$} & \multicolumn{5}{|c|}{ Carbon mineralization (mg/kg) } \\
\hline & $0 \mathrm{mg} \mathrm{N}$ & $1 \mathrm{mg} \mathrm{N}^{\mathrm{y}}$ & $2 \mathrm{mg} \mathrm{N}$ & $3 \mathrm{mg} \mathrm{N}$ & MSD N-rate \\
\hline \multicolumn{6}{|c|}{$0-7$ days } \\
\hline $0.48 \mathrm{~cm} \mathrm{CCR}$ & 2370 & 3236 & 3584 & 3882 & 113 \\
\hline $0.95 \mathrm{~cm} \mathrm{CCR}$ & 1757 & 2593 & 2987 & 3414 & 154 \\
\hline $\mathrm{PB}$ & 1918 & 2311 & 2367 & 2478 & 111 \\
\hline $\mathrm{PM}$ & 143 & 94 & 614 & 258 & 335 \\
\hline MSD Substrate & 84 & 121 & 284 & 170 & \\
\hline \multicolumn{6}{|c|}{$8-15$ days } \\
\hline $0.48 \mathrm{~cm} \mathrm{CCR}$ & 2615 & 2827 & 2888 & 3358 & 183 \\
\hline $0.95 \mathrm{~cm} \mathrm{CCR}$ & 2200 & 2620 & 3105 & 3706 & 209 \\
\hline $\mathrm{PB}$ & 1625 & 1986 & 1944 & 2021 & 329 \\
\hline PM & 356 & 384 & 353 & 371 & 117 \\
\hline MSD Substrate & 283 & 140 & 172 & 149 & \\
\hline \multicolumn{6}{|c|}{$16-30$ days } \\
\hline $0.48 \mathrm{~cm} \mathrm{CCR}$ & 3479 & 3615 & 3631 & 3436 & 134 \\
\hline $0.95 \mathrm{~cm} \mathrm{CCR}$ & 3229 & 3556 & 3728 & 3714 & 225 \\
\hline $\mathrm{PB}$ & 2254 & 2485 & 2585 & 2586 & 129 \\
\hline $\mathrm{PM}$ & 751 & 591 & 578 & 641 & 166 \\
\hline MSD Substrate & 195 & 139 & 123 & 126 & \\
\hline \multicolumn{6}{|c|}{$31-60$ days } \\
\hline $0.48 \mathrm{~cm} \mathrm{CCR}$ & 4133 & 3812 & 3721 & 3837 & 459 \\
\hline $0.95 \mathrm{~cm} \mathrm{CCR}$ & 4082 & 4211 & 4041 & 3767 & 324 \\
\hline $\mathrm{PB}$ & 2950 & 3173 & 3356 & 3417 & 190 \\
\hline $\mathrm{PM}$ & 1723 & 1682 & 1581 & 1582 & 258 \\
\hline MSD Substrate & 355 & 166 & 238 & 248 & \\
\hline \multicolumn{6}{|c|}{ Total: 0-60 days } \\
\hline $0.48 \mathrm{~cm} \mathrm{CCR}$ & 12360 & 13414 & 13778 & 14108 & 609 \\
\hline $0.95 \mathrm{~cm} \mathrm{CCR}$ & 11016 & 13110 & 14377 & 14624 & 799 \\
\hline $\mathrm{PB}$ & 8954 & 10097 & 10313 & 10484 & 422 \\
\hline $\mathrm{PM}$ & 2989 & 2922 & 2762 & 2781 & 440 \\
\hline MSD Substrate & 668 & 405 & 662 & 409 & \\
\hline
\end{tabular}

${ }^{7}$ CCR: clean chip residual, PB: pine bark, and PM: sphagnum peatmoss.

y 2000 ppm stock solution of $\mathrm{NH}_{4} \mathrm{NO}_{3}(0,0.5,1.0,1.5 \mathrm{~mL})$.

${ }^{\mathrm{x}}$ MSD based on Waller-Duncan $k$ ratio $t$-tests $(\alpha=0.05)$.

than the other rates, though the values were similar to 0 and $2 \mathrm{mg} \mathrm{N}$.

Clean chip residual consistently had the greatest amount of microbial respiration among the substrates over the course of the incubation period (0-60 DAT) (Table 4). At $0 \mathrm{mg} \mathrm{N}$ rate, $0.48 \mathrm{~cm}$ CCR had greater microbial respiration than $0.95 \mathrm{~cm}$, but at 1 and $2 \mathrm{mg} \mathrm{N}$ it was similar. At $3 \mathrm{mg} \mathrm{N}$, $0.95 \mathrm{~cm}$ CCR had greater microbial respiration than $0.48 \mathrm{~cm}$ CCR. Pine bark and PM were different from each other and less than CCR treatments for microbial respiration. Across the $\mathrm{N}$ rates for $0.48 \mathrm{~cm}$ CCR, microbial respiration increased with increasing $\mathrm{N}$ rate. For $0.95 \mathrm{~cm} \mathrm{CCR,} \mathrm{microbial}$ respiration increased with increasing $\mathrm{N}$ rate, though 2 and $3 \mathrm{mg} \mathrm{N}$ were similar. Pine bark was similar at 1,2 , and $3 \mathrm{mg}$ $\mathrm{N}$ rates, only $0 \mathrm{mg} \mathrm{N}$ had less microbial respiration. There were no differences in microbial respiration across $\mathrm{N}$ rates for PM.

3.3. Total Inorganic $N$ (Plant Available N). At 7 DAT, PM had more $\mathrm{N}$ than all other treatments; all other treatments were similar (Table 5). At 2 and $3 \mathrm{mg} \mathrm{N}, \mathrm{PM}$ had the most $\mathrm{N}$ followed by $\mathrm{PB}$ and the CCR treatments, which were similar to each other. Across $\mathrm{N}$ rates for $0.48 \mathrm{~cm}$ CCR and PB, $3 \mathrm{mg} \mathrm{N}$ had more $\mathrm{N}$ than other rates, which were similar. For $0.95 \mathrm{~cm}$ CCR, $\mathrm{N}$ increased with increasing $\mathrm{N}$ rate, though 0 and $2 \mathrm{mg}$ $\mathrm{N}$ were similar. Peatmoss had greater available $\mathrm{N}$ as $\mathrm{N}$ rate increased.

Total inorganic $\mathrm{N}$ at 15 DAT showed that at 0 and $1 \mathrm{mg}$ $\mathrm{N}$ PM had the greatest amount of available $\mathrm{N}$ followed by PB and CCR treatments, which were all similar to each other 
TABLE 5: Total inorganic nitrogen $\left(\mathrm{NH}_{4}\right.$ and $\left.\mathrm{NO}_{3}\right)$ mineralization in clean chip residual, pine bark and peatmoss substrates.

\begin{tabular}{|c|c|c|c|c|c|}
\hline \multirow{2}{*}{ Substrate ${ }^{z}$} & \multicolumn{5}{|c|}{ Nitrogen mineralization (mg/kg) } \\
\hline & $0 \mathrm{mg} \mathrm{N}$ & $1 \mathrm{mg} \mathrm{N}^{\mathrm{y}}$ & $2 \mathrm{mg} \mathrm{N}$ & $3 \mathrm{mg} \mathrm{N}$ & MSD N-rate \\
\hline \multicolumn{6}{|c|}{ 0-7 days } \\
\hline $0.48 \mathrm{~cm} \mathrm{CCR}$ & 31 & 28 & 37 & 128 & 16 \\
\hline $0.95 \mathrm{~cm} \mathrm{CCR}$ & 44 & 77 & 262 & 515 & 174 \\
\hline $\mathrm{PB}$ & 44 & 56 & 440 & 1458 & 459 \\
\hline PM & 1753 & 2549 & 3359 & 5264 & 790 \\
\hline MSD Substrate & 130 & 174 & 250 & 850 & \\
\hline \multicolumn{6}{|c|}{$0-15$ days } \\
\hline $0.48 \mathrm{~cm} \mathrm{CCR}$ & 58 & 61 & 42 & 50 & 55 \\
\hline $0.95 \mathrm{~cm} \mathrm{CCR}$ & 53 & 52 & 64 & 168 & 79 \\
\hline $\mathrm{PB}$ & 5 & 88 & 293 & 1572 & 442 \\
\hline PM & 1619 & 2937 & 3610 & 5869 & 588 \\
\hline MSD Substrate & 169 & 281 & 169 & 630 & \\
\hline \multicolumn{6}{|c|}{$0-30$ days } \\
\hline $0.48 \mathrm{~cm} \mathrm{CCR}$ & 101 & 148 & 99 & 80 & 67 \\
\hline $0.95 \mathrm{~cm} \mathrm{CCR}$ & 114 & 116 & 102 & 310 & 119 \\
\hline $\mathrm{PB}$ & 75 & 108 & 152 & 1061 & 82 \\
\hline PM & 2530 & 3591 & 4043 & 6149 & 768 \\
\hline MSD Substrate & 342 & 429 & 356 & 402 & \\
\hline \multicolumn{6}{|c|}{ 0-60 days } \\
\hline $0.48 \mathrm{~cm} \mathrm{CCR}$ & 63 & 87 & 91 & 117 & 44 \\
\hline $0.95 \mathrm{~cm} \mathrm{CCR}$ & 91 & 142 & 121 & 142 & 34 \\
\hline $\mathrm{PB}$ & 33 & 39 & 58 & 761 & 94 \\
\hline $\mathrm{PM}$ & 1806 & 2632 & 3533 & 5404 & 783 \\
\hline MSD Substrate & 44 & 150 & 205 & 734 & \\
\hline
\end{tabular}

${ }^{\mathrm{z}} \mathrm{CCR}$ : clean chip residual, $\mathrm{PB}$ : pine bark, and PM: sphagnum peatmoss.

y 2000 ppm stock solution of $\mathrm{NH}_{4} \mathrm{NO}_{3}(0,0.5,1.0,1.5 \mathrm{~mL})$.

${ }^{\mathrm{x}}$ MSD based on Waller-Duncan $k$ ratio $t$-tests $(\alpha=0.05)$.

(Table 5). At 2 and $3 \mathrm{mg} \mathrm{N}$, PM had the highest $\mathrm{N}$ followed by $\mathrm{PB}$ and the two CCR treatments, which were similar to each other. There was no significant difference in available $\mathrm{N}$ for $0.48 \mathrm{~cm}$ CCR across $\mathrm{N}$ rates. For $0.95 \mathrm{~cm}$ CCR and PB, the greatest amount of available $\mathrm{N}$ was with $3 \mathrm{mg} \mathrm{N}$, all other $\mathrm{N}$ rates had less $\mathrm{N}$ and were similar to each other. Peatmoss had increasingly available $\mathrm{N}$ as $\mathrm{N}$ rate increased.

At 30 DAT, results for total available $\mathrm{N}$ were similar to results at 15 DAT, with one exception: among substrates treated with $2 \mathrm{mg}$ supplemental N, PM had the greatest amount of $\mathrm{N}$ and all other treatments were similar (Table 5). Also for PM, 1 and $2 \mathrm{mg} \mathrm{N}$ were similar, though the trend continued toward having more available $\mathrm{N}$ as $\mathrm{N}$ rate increased.

Peatmoss had the most available $\mathrm{N}$ at all $\mathrm{N}$ rates among substrates at 60 DAT (Table 5). At $0 \mathrm{mg} \mathrm{N}, 0.95 \mathrm{~cm} \mathrm{CCR} \mathrm{had}$ greater $\mathrm{N}$ than $\mathrm{PB}$. For all other $\mathrm{N}$ rates, CCR and $\mathrm{PB}$ had similar available $\mathrm{N}$, though less than PM. Across $\mathrm{N}$ rates, there were no differences for $0.48 \mathrm{~cm}$ CCR. For the remainder of the substrates, available $\mathrm{N}$ increased with increasing $\mathrm{N}$ rates.

\section{Discussion}

Incubation studies have previously been used to evaluate $\mathrm{N}$ immobilization for horticultural purposes. A study by Hartz and Giannini [11] reported short-term net N-immobilization (2-week aerobic incubation) in samples of composted municipal yard and landscape wastes from three locations, with an overall trend toward decreased immobilization with increased compost age. At least 9-12 weeks of composting were required to minimize the undesirable characteristics of immature compost. Compost materials generally provide enough $\mathrm{N}$ to negate the use of supplemental fertilizer; however, materials such as PB, PM, and CCR do not contain adequate $\mathrm{N}$ to support plant growth and require fertilization before use in plant production.

A subsequent study by Hartz et al. [12] determined the $\mathrm{N}$ and $\mathrm{C}$ mineralization rates of 19 manure and compost samples for use as soil amendments in vegetable production in 1996 and 12 additional samples in 1997. Net $\mathrm{N}$ mineralization was measured at 4- or 8-week intervals while 
C mineralization was measured at 4-week intervals. An average of $16 \%, 7 \%$, and $1 \%$ of organic $\mathrm{N}$ was mineralized after 12 weeks in 1996, and an average of 15\%,6\%, and $2 \%$ was mineralized after 24 weeks of incubation for 1997 , in manure, manure compost, and plant residue compost, respectively. Mineralization of manure C averaged 35\% of initial C content after 24 weeks, while compost averaged only $14 \%$. Within 4 (compost) or 16 weeks (manure), the rate of mineralization of amendment $\mathrm{C}$ had declined to a level similar to soil organic C.

Waste paper as a substitute for PM displays significant Nimmobilization and high $\mathrm{pH}$ [13]. An incubation study was conducted to define the $\mathrm{N}$ status of the paper medium. Initial results indicated diminished plant growth in pure paper substrate. The amount of additional $\mathrm{N}$ needed was difficult to predict during cultivation. A composting process was deemed necessary to overcome $\mathrm{N}$-immobilization and lower $\mathrm{pH}$ and to improve water-conducting properties of the substrate.

When manure compost is used, $\mathrm{N}$-immobilization will eventually stop and $\mathrm{N}$-mineralization will begin. In the previous cases, $\mathrm{N}$ was provided to the plant instead of being removed, resulting in competition between plants and microbes for N. Our results indicate that $\mathrm{N}$ became available for $0.95 \mathrm{~cm}$ CCR during the course of our study, but the change was small relative to the loss of $\mathrm{N}$ from PM.

While CCR exhibits high microbial respiration (particularly with smaller particle sizes), microbial activity and $\mathrm{N}$ immobilization were generally similar to PB. Clean chip residual screened to $0.48 \mathrm{~cm}$ was more microbially active, most likely due to increased surface area resulting from smaller particle size. Since CCR has an inherently high percentage of PB (35\%), it tends to perform similarly; the addition of $40 \%$ wood fiber does not seem to inhibit plant growth or require amendment changes in nursery crop production. This study indicated that almost no management differences should be expected for crops produced in CCR compared to PB.

Peatmoss had virtually no microbial activity as measured by respiration in this study. However, unlike PB and CCR this was not due to $\mathrm{N}$ limitation as there was no indication that respiration was impacted at all by the addition of $\mathrm{N}$. While it is clear that the remaining materials produced significant immobilization of the fertilizer $\mathrm{N}$, there was little or no difference between PB and CCR. While PB did have increased $\mathrm{N}$ levels at the highest supplemental rate, this was miniscule compared to PM and does not imply a need to change management. In fact, $\mathrm{N}$ levels in PB decreased over time compared to CCR, which showed slow increases in N. For example, at $2 \mathrm{mg}$ supplemental $\mathrm{N} \mathrm{PB}$ had $440 \mathrm{mg} \cdot \mathrm{kg}^{-1}$ available $\mathrm{N}$ at $7 \mathrm{DAT}$, which was reduced to $58 \mathrm{mg} \cdot \mathrm{kg}^{-1}$ by day 60 . On the other hand, CCR had $37 \mathrm{mg} \cdot \mathrm{kg}^{-1}$ at 7 DAT but increased to $91 \mathrm{mg} \cdot \mathrm{kg}^{-1}$ by 60 DAT. This indicates that while the immobilization of $\mathrm{N}$ was similar in $\mathrm{PB}$ and CCR, it may have increased in $\mathrm{PB}$ over time. This is reflected in respiration where there initially was much lower microbial respiration from $\mathrm{PB}$, but by 31-60 DAT the respiration rate was similar to CCR and much more responsive to changes in supplemental $\mathrm{N}$ rate. This indicates that $\mathrm{PB}$ became more inclined toward $\mathrm{N}$-immobilization as time progressed.
In the current study, $\mathrm{pH}$ and $\mathrm{EC}$ of CCR were determined to be acceptable for plant culture. In fact, CCR may not require a limestone amendment to raise $\mathrm{pH}$. Since $0.95 \mathrm{~cm}$ CCR and $\mathrm{PB}$ have similar particle size distributions, we recommend this screen size for 1-gal. containers on outdoor beds, while $0.48 \mathrm{~cm}$ CCR is more suitable for greenhouse production. Since many PM suppliers premix amendments into shipped products, it is essential to determine the correct fertilization amendments so that substrates composed of CCR can perform similarly to PM. The results of this study indicate that growers should not be concerned about short-term negative impacts from $\mathrm{N}$-immobilization in CCR (compared to $\mathrm{PB}$ ).

\section{References}

[1] W. Lu, J. L. Sibley, C. H. Gilliam, J. S. Bannon, and Y. Zhang, "Estimation of U.S. bark generation and implications for horticultural industries," Journal of Environmental Horticulture, vol. 24, pp. 29-34, 2006.

[2] W. R. Carlile, "Growing media and the environment lobby in the UK 1997-2001," Acta Horticulturae, vol. 644, pp. 107-113, 2004.

[3] S. Holmes, "Peat and peat alternatives: their use in commercial horticulture in England and Wales in 2003," A Report for Horticulture and Potatoes Division, Department for Environment, Food and Rural Affairs, ADAS Horticulture, Boxworth, UK, 2004.

[4] C. R. Boyer, G. B. Fain, C. H. Gilliam, T. V. Gallagher, H. A. Torbert, and J. L. Sibley, "A new substrate for container-grown plants: Clean Chip Residual," Procedures of the International Plant Propagators Society, vol. 56, pp. 553-559, 2006.

[5] C. R. Boyer, G. B. Fain, C. H. Gilliam, T. V. Gallagher, H. A. Torbert, and J. L. Sibley, "Clean chip residual (CCR) substrate for container-grown perennials: Effect of supplemental nitrogen rates," HortScience, vol. 42, p. 439, 2007.

[6] C. R. Boyer, G. B. Fain, C. H. Gilliam, T. V. Gallagher, H. A. Torbert, and J. L. Sibley, "Clean chip residual: a substrate component for growing annuals," HortTechnology, vol. 18, no. 3, pp. 423-432, 2008.

[7] C. R. Boyer, C. H. Gilliam, G. B. Fain, T. V. Gallagher, H. A. Torbert, and J. L. Sibley, "Production of woody nursery crops in clean chip residual substrate," Journal of Environmental Horticulture, vol. 27, pp. 56-62, 2009.

[8] S. W. Kenna and C. E. Whitcomb, "Hardwood chips as an alternative medium for container plant production," HortScience, vol. 20, pp. 867-869, 1985.

[9] N. Gruda, S. V. Tucher, and W. H. Schnitzler, "N-immobilization of wood fiber substrates in the production of tomato transplants," Journal of Applied Botany, vol. 74, no. 1-2, pp. 32-37, 2000.

[10] T. E. Bilderback, W. C. Fonteno, and D. R. Johnson, "Physical properties of media composed of peanut hulls, pine bark and peatmoss and their effects on azalea growth," Journal of the American Society for Horticultural Science, vol. 107, pp. 522$525,1982$.

[11] T. K. Hartz and C. Giannini, "Duration of composting of yard wastes affects both physical and chemical characteristics of compost and plant growth," HortScience, vol. 33, no. 7, pp. 1192-1196, 1998. 
[12] T. K. Hartz, J. P. Mitchell, and C. Giannini, "Nitrogen and carbon mineralization dynamics of manures and composts," HortScience, vol. 35, no. 2, pp. 209-212, 2000.

[13] H. D. Molitor and U. Brúckner, "Waste paper-a substitute for peat in horticulture," Acta Horticulturae, vol. 450, pp. 47-55, 1997. 


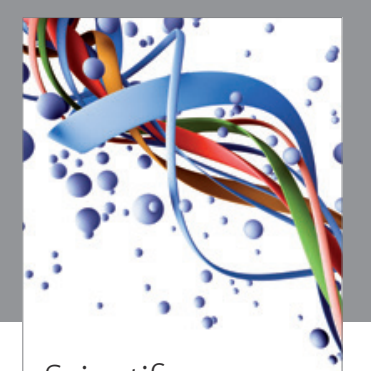

Scientifica
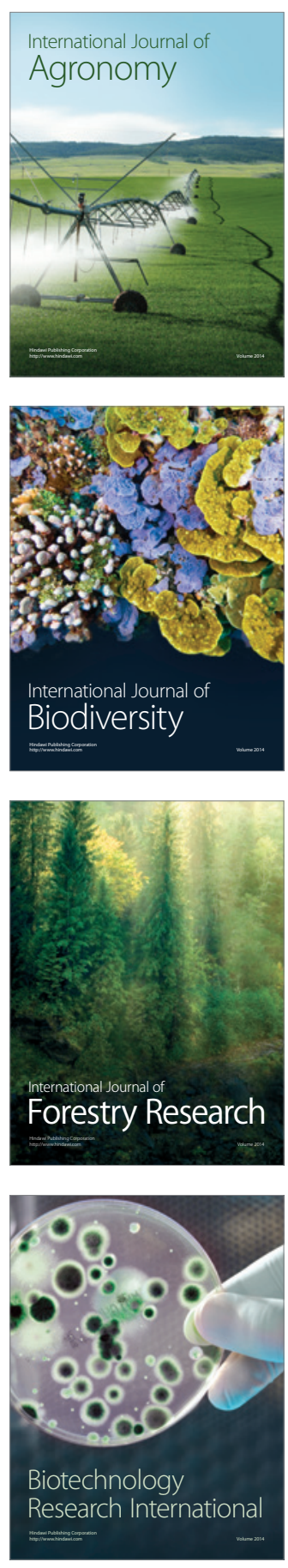
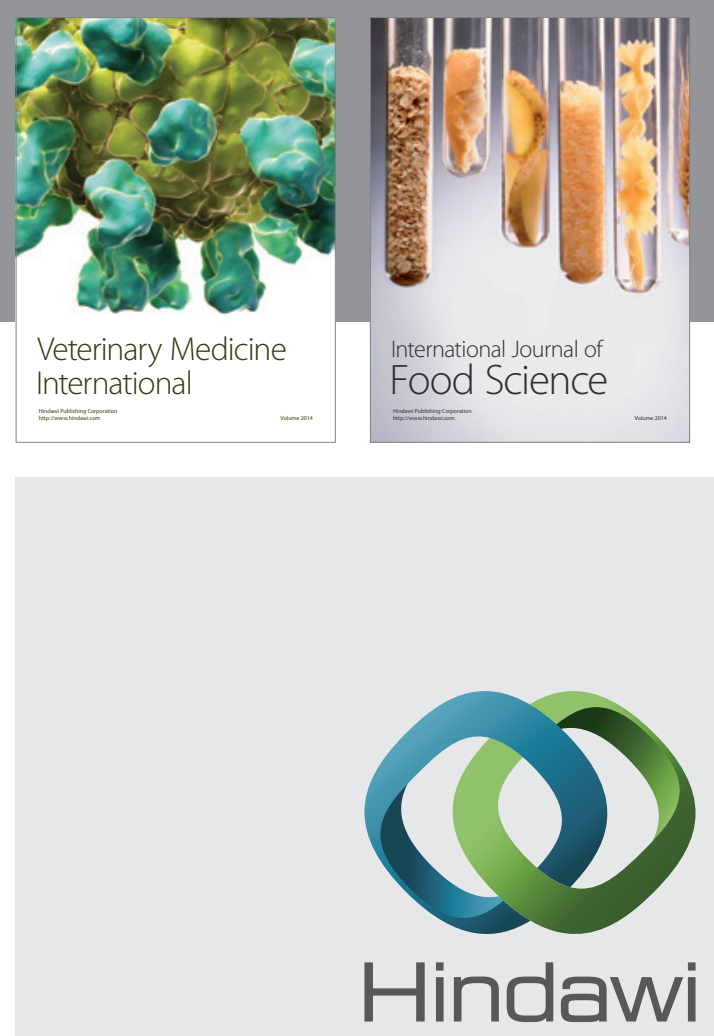

Submit your manuscripts at

http://www.hindawi.com
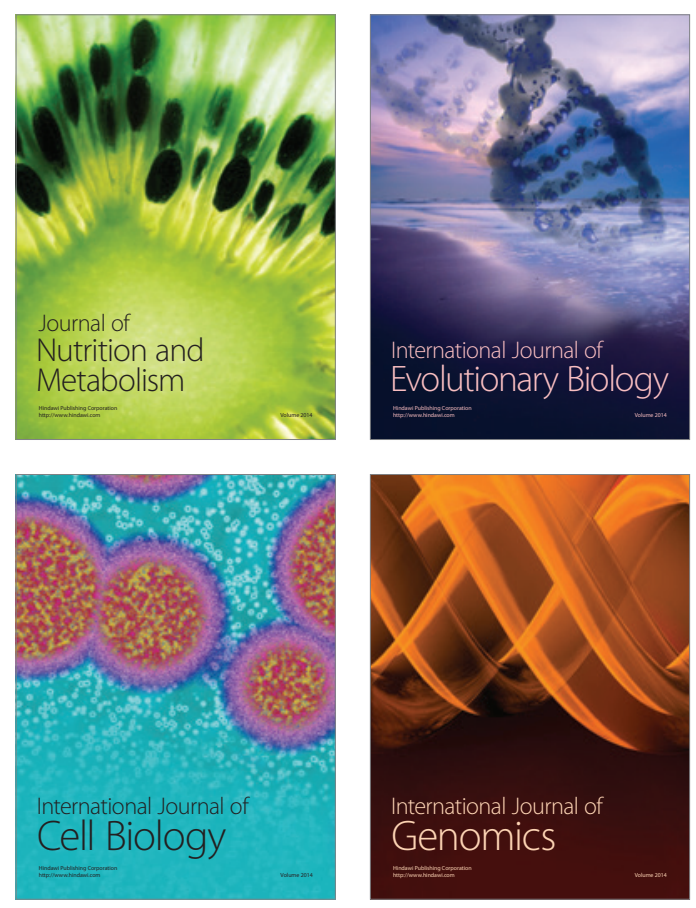
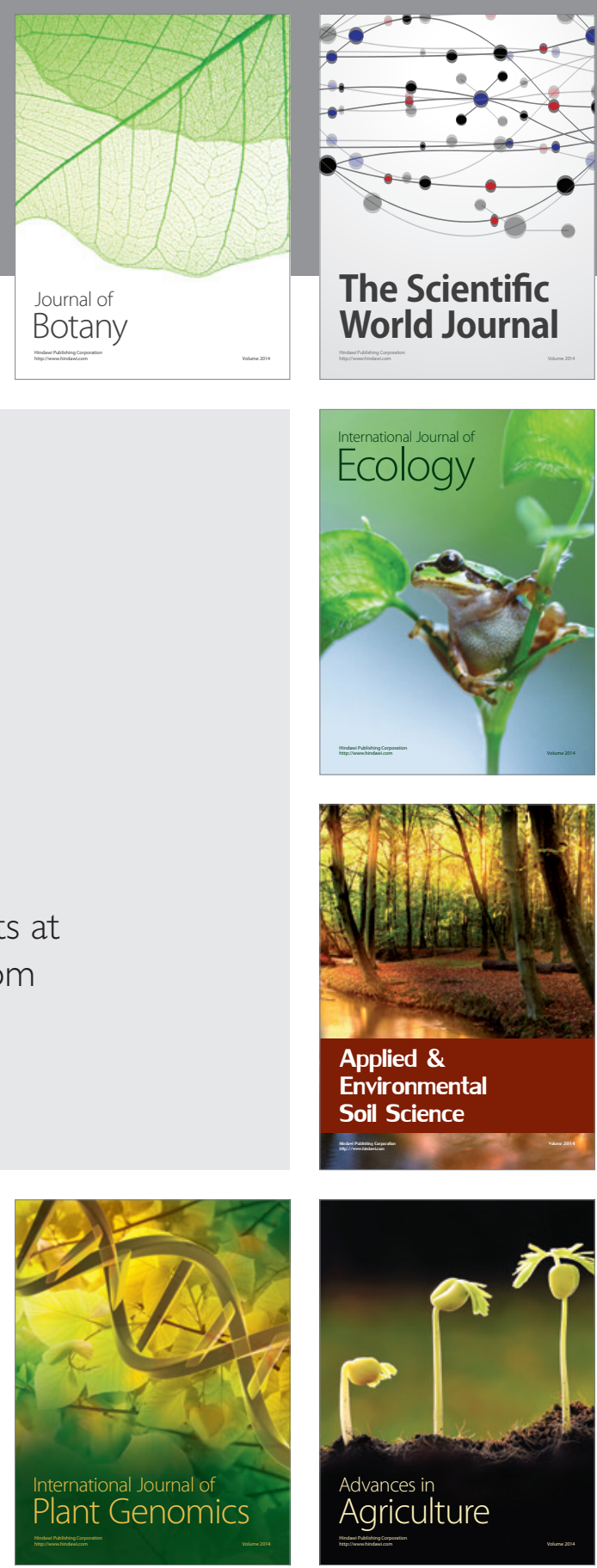

The Scientific World Journal
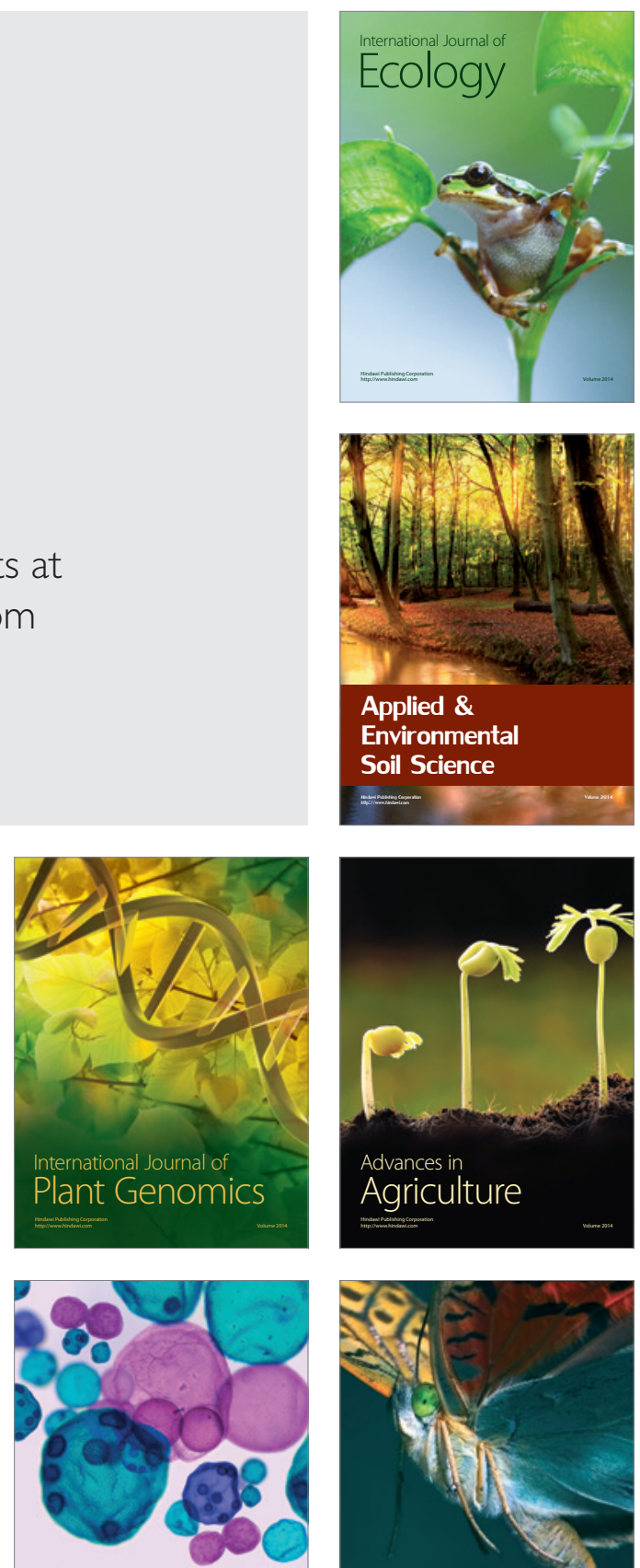

International Journal of Microbiology

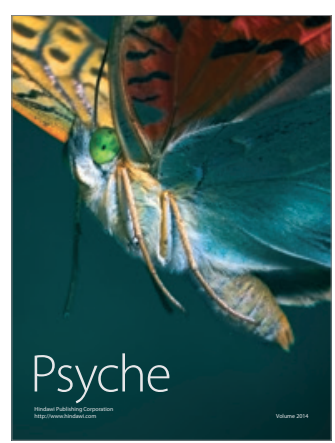

